10IKC-97

\title{
ORIGIN OF DIAMONDS FROM THE DACHINE ULTRAMAFIC, FRENCH GUYANA
}

\author{
Smith* CB ${ }^{1}$, Bulanova GP1, Walter MJ ${ }^{1}$, Kohn SC ${ }^{1}$, Mikhail S ${ }^{2,3}$, Gobbo L ${ }^{4}$ \\ ${ }^{1}$ School of Earth Sciences, University of Bristol, United Kingdom, \\ ${ }^{2}$ University College London, Earth Sciences, London, United Kingdom. \\ ${ }^{3}$ PSSRI, The Open University, Milton Keynes, United Kingdom,
}

${ }^{4}$ Rio Tinto Exploration, Brasilia, Brazil; *corresponding author: chris_b_smith@btopenworld.com

\section{INTRODUCTION}

Dachine diamonds are highly unusual, being i) exhumed much earlier in Earth's history than almost any other diamonds; ii) not being hosted in kimberlite; and iii) having low nitrogen concentrations and aggregation, features only explainable by extraordinarily short mantle residence times or growth at anomalously low temperatures. We describe here their external morphology, internal structure, mineral inclusions, nitrogen content and aggregation, carbon and nitrogen isotope composition, and discuss their manner of genesis.

\section{GEOLOGICAL SETTING}

The Dachine Palaeoproterozoic diamondiferous host rock is a metamorphosed pyroclastic ultramafic intercalated within the $2.11 \mathrm{Ga}$ arc-type Lower Paramaca metavolcanics in the southern greenstone belt of French Guyana (Fig. 1) (Bailey, 1999; Capdevila et al., 1999).

Metamorphism occurred during a Transamazonian crustal accretion event affecting the Guiana Shield which forms the northern part of the Amazon Craton. The Paramaca series consists mainly of metabasalts and overlying felsic gneisses derived from volcanic sediments, dacite and rhyolite tuffs and lavas. The diamondiferous ultramafic unit has been metamorphosed to a talc schist with volcaniclastic textures preserved (Bailey, 1999).

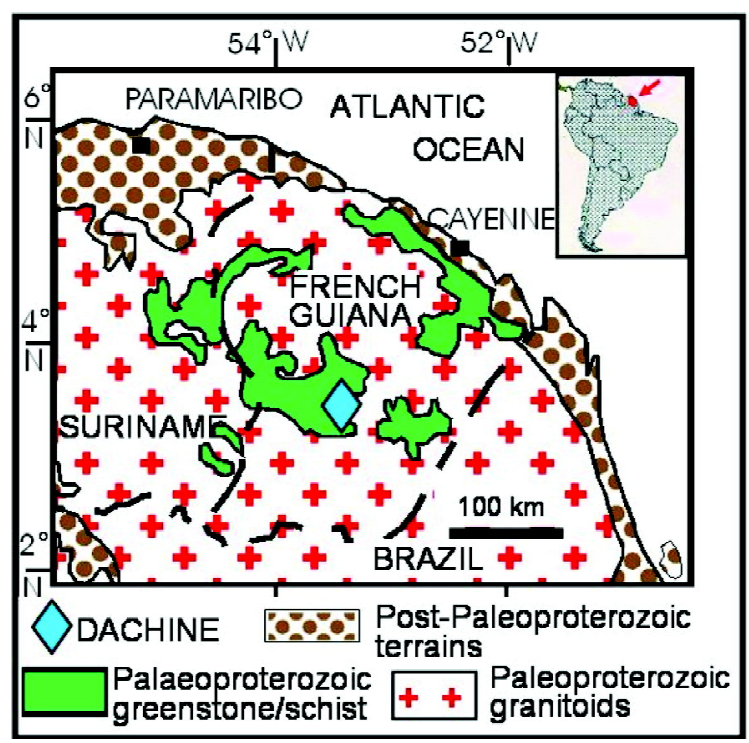

Fig. 1. Geological setting and location of Dachine diamond deposit

The diamond occurrence is unique in that the host ultramafic is not a kimberlite or lamproite primary host with which diamonds are normally associated. It has been variously described as a komatiite based on major and trace element chemistry (Bailey, 1999; Capdevila et al., 1999), a picritic shoshonite (Magee and Taylor, 1999; Magee, 2001) from accessory chromite compositions, or an adakitic lamprophyre (Wyman et al., 2008) from resemblances with diamondiferous lamprophyres at Wawa in Quebec. Due to element mobility during weathering and metamorphism, primary rock chemistry may not be definitive. But the very high temperatures and lack of volatiles associated with komatiite make it unlikely that diamond would survive during transport to 


\section{$1^{\text {th }}$ International Kimberlite Conference, Bangalore - 2012}

surface in such a host rock; hence a lamprophyric host is favoured.

\section{DIAMOND MORPHOLOGY}

The diamonds are typically small $(\sim 1 \mathrm{~mm}$ or less), pale greyish yellow to pale brown, poorly shaped, irregular, step-layered octahedra ( $71 \%$ of stones examined), commonly in aggregate form. Minor cubo-octahedra are present $(15 \%)$; there is only rare very slight resorption $(11 \%)$ but deep etch channels are common.

\section{ULTRAVIOLET AND CATHODOLUMINESCENCE}

Cathodoluminescence studies of polished plates of the Dachine diamonds reveal often complex polycentric internal structures (Fig. 2a, 2b) with blocky growth and intensive plastic deformation in the form of linear dislocations, giving rise to tatami (Fig. 2d) or granular effects (Fig. 2 a, b). Etched out cracks are common around the crystal margins; the cracks usually follow structural dislocations, but occasionally are curved. In only one case where cuboid features were discernable was fibrous growth at the rim revealed (Fig. 2c).

Twenty one stones were examined under long wavelength ultraviolet light, 8 showing no apparent luminescence, 8 exhibiting a combination of pale yellowish green with pale blue patches, 3 were pale blue, and 2 fluoresced pale pink.

\section{MINERAL INCLUSIONS IN DIAMONDS AND ACCESSORY MINERALS IN DACHINE ROCK CONCENTRATES}

Syngenetic mineral inclusions of silicates and sulphides from 23 Dachine diamonds were analysed by electron microprobe. Results for silicates are given in Table 1 .
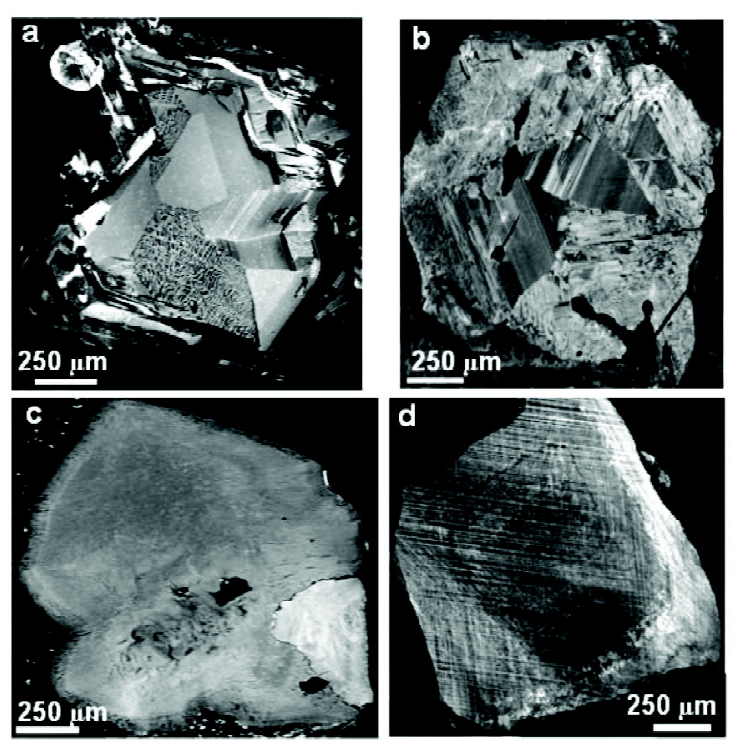

Fig. 2. Cathodoluminescence images of four Dachine diamonds showing representative internal structures. a) Irregular octahedral aggregate external form; polycentric cubo-octahedral blocky sectorial core, in part showing vermiform granular texture due to possible plastic deformation dislocation networks, overgrown by octahedral rim zone. b) Irregular octahedral diamond with blocky polycentric internal structure and deep etch channel (bottom-right); c) Cubooctahedron with weak internal zonation, fibrous rim and one apparent separate block in SE; d) Diamond with cubo-octahedral zoning and plastic deformation ("tatami" structure).

Table 1. Electron microprobe analyses of syngenetic silicate mineral inclusions from Dachine diamonds.

\begin{tabular}{llllll}
\hline Diamond & 4A-5 & 4A-11 & 4B-2 & 4A-2 & 4B-7 \\
\hline Mineral & & Garnet & \multicolumn{3}{c}{ Clinopyroxene } \\
\hline $\mathrm{SiO}_{2}$ & 37.60 & 38.51 & 39.89 & 54.66 & 52.13 \\
$\mathrm{TiO}_{2}$ & 0.62 & 0.85 & 0.60 & 0.14 & 0.15 \\
$\mathrm{Al}_{2} \mathrm{O}_{3}$ & 20.08 & 20.39 & 20.49 & 6.72 & 0.98 \\
$\mathrm{Cr}_{2} \mathrm{O}_{3}$ & 0.05 & 0.06 & 0.08 & 0.14 & 0.00 \\
$\mathrm{FeO}^{\mathrm{T}}$ & 12.51 & 6.68 & 8.01 & 9.44 & 7.78 \\
$\mathrm{MnO}$ & 15.11 & 18.77 & 12.78 & 0.09 & 4.60 \\
$\mathrm{MgO}$ & 4.99 & 5.98 & 6.90 & 8.62 & 14.59 \\
$\mathrm{CaO}$ & 7.67 & 8.64 & 10.15 & 16.89 & 17.88 \\
$\mathrm{Na} 2 \mathrm{O}$ & 0.03 & 0.03 & 0.12 & 3.43 & 0.44 \\
$\mathrm{~K}_{2} \mathrm{O}$ & 0.00 & 0.01 & 0.00 & 0.02 & 0.21 \\
$\mathrm{ZnO}$ & 0.01 & 0.06 & & 0.00 & 0.22 \\
\hline Total & 98.66 & 99.97 & 99.01 & 100.31 & 98.97 \\
\hline
\end{tabular}

Note: $\mathrm{FeO}^{\mathrm{T}}$ is total iron as $\mathrm{FeO}$ 


\section{$1^{\text {th }}$ International Kimberlite Conference, Bangalore - 2012}

The identification of syngenesis is based on these inclusions not being associated with cracks leading to surface, and on their having octahedral morphology imposed on them by the diamond (Fig. 3) (Bulanova et al., 2005). The common hexagonal inclusion shapes are off-centre dodecahedral plane cross sections of octahedral crystals, demonstrating their diamond-imposed morphology (Bulanova et al., op. cit.). Sulphide inclusions, mainly low-Ni pyrrhotites or pyrrhotite +pentlandite, with minor chalcopyrite, were analysed from 19 diamonds. Spessartinegrossular-almandine-pyrope garnets were found in 3 diamonds and two stones contained omphacite (Table 1). The garnets and clinopyroxenes were also analysed for trace elements by SIMS and chondrite-normalised REE compositions are shown in Fig. 4

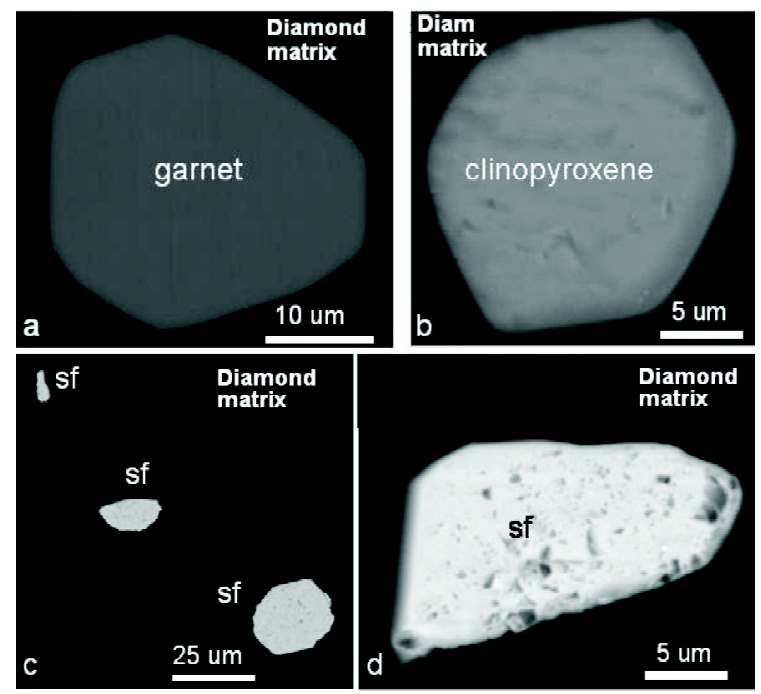

Fig. 3. Back-scattered SEM imagery of syngenetic mineral inclusions in Dachine diamonds: a) Mn-rich garnet (diamond 4A-11), b) clinopyroxene (4B-07) c) three pyrrhotite sulphide inclusions (4A08), d) pyrrhotite (4B-10); note holes in sulphide suggestive of fluid/ gas egress. Note the frequent hexagonal shaped morphology imposed on the inclusions by the diamonds.

\section{FOURIER TRANSFORM INFRARED SPECTROSCOPY}

FTIR measurements on Dachine stones show that some $50 \%$ of stones have $\mathrm{N}$ below level

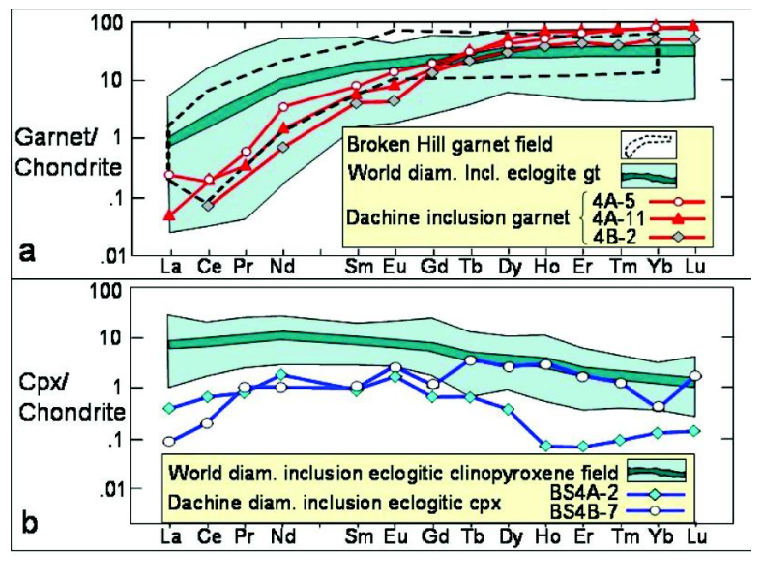

Fig. 4. a) REE concentrations for Dachine diamond inclusion garnets normalised against C1 chondrite (Sun and McDonough, 1989), compared to world-wide garnet data (Stachel et al., 2004) from eclogitic diamond inclusions and to Broken Hill sulphide association garnets (Schwandt et al., 1992); b) REE plot of Dachine diamond inclusion clinopyroxenes normalised against $\mathrm{C} 1$ chondrite, compared to the worldwide field for eclogitic diamond inclusion clinopyroxenes (Stachel et al., 2004).

of detection and would be classified as Type II $(<20 \mathrm{ppm} \mathrm{N}$, as defined by Cartigny, 2005). Detected $\mathrm{N}$ values range up to $\sim 100 \mathrm{ppm}$ with the spectra mainly showing the Ib-IaA aggregation state with $\mathrm{Ib}$ often dominant (Fig. 4). Several stones show a peak at $1150-1160 \mathrm{~cm}^{-1}$ which lies between the $\mathrm{IaB}$ and $\mathrm{Ib}$ peak positions.

\section{STABLE ISOTOPE COMPOSITIONS}

Results of stepped combustion isotopic analyses are shown in Fig. 5. This shows the total range for samples in this study. This range of isotopic values is anomalous to other mantle diamond populations for both $\mathrm{C}$ and $\mathrm{N} \cdot \mathrm{d}^{13} \mathrm{C}$ ranged from +3 to $-36 \%$, and $\mathrm{d}^{15} \mathrm{~N}$ from circa -5 to $>+33 \%$. It is noteworthy that no samples from this study or Cartigny (2010) exhibit coupled $\mathrm{d}^{13} \mathrm{C}-\mathrm{d}^{15} \mathrm{~N}$ values around the mean mantle field.

\section{DISCUSSION}

\section{DIAMOND GROWTH CONDITIONS}

The dominant, poorly shaped, octahedral and cubo-octahedral aggregate forms, the 


\section{0 $^{\text {th }}$ International Kimberlite Conference, Bangalore - 2012}

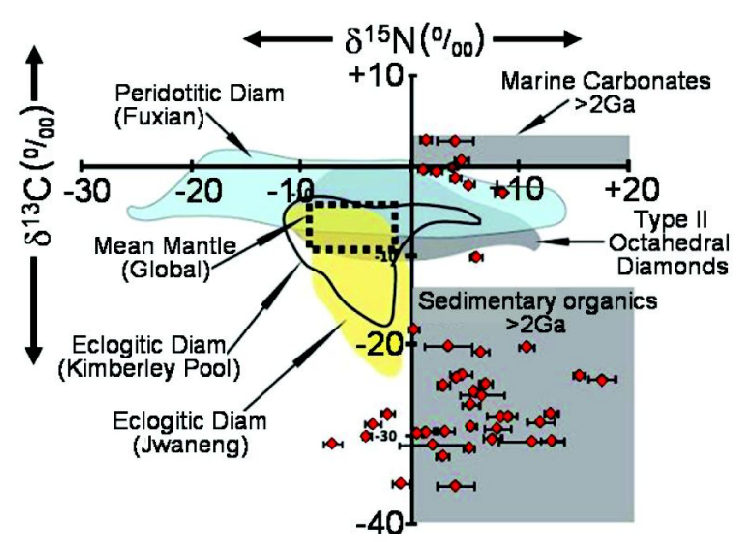

Fig. 5. $\delta^{15} \mathrm{~N} v \delta^{13} \mathrm{C}$ plot of isotopic compositions of Dachine diamonds (red diamond symbols) determined by stepped combustion mass analysis, compared to global sources.

polycentric, blocky internal structures, and the small size of Dachine stones suggest rapid crystallisation. The relative lack of resorption indicates quick transport to surface. The plastic deformation, often localised to individual internal blocky growth centres, implies periodic high stress conditions during growth.

\section{MINERAL CHEMISTRY AND THERMOBAROMETRY}

\section{Sulphides}

Pyrrhotite and re-calculated former low-Ni monosulphide solid solution $(\mathrm{Po}+\mathrm{Pn})$ are indicative of eclogitic paragenesis of the diamonds.

\section{Garnets}

Garnets occur as syngenetic inclusions in three diamonds and have most unusual almandinespessartite-grossular-pyrope compositions (Table 1; Fig. 4) and lack $\mathrm{Cr}_{2} \mathrm{O}_{3}(<0.1 \%)$. $\mathrm{MnO}$ values range from $13-19 \mathrm{wt} \%$. Such compositions have never been reported from diamond inclusions elsewhere and generally are rare in nature. Their chemistry resembles garnets associated with exhalative sulphides ore bodies such as in skarn haloes around Broken Hill type deposits (Spry and Wonder, 1989) or Abitibi VMS-type bodies (Dube et al., 2007), but the pyrope component at Dachine is much higher.

Dachine diamond inclusion garnets have an eclogitic-style REE pattern (Fig. 4) and a similar pattern to Broken Hill sulphide-associated garnets, but are essentially LREE-depleted \& HREEenhanced in detailed comparison. Negative $\mathrm{Eu}$ anomalies are displayed by two garnets, apparently corresponding with positive Eu anomalies in the clinopyroxenes.

It is important to note that garnets from Dachine drill core concentrates are predominately crustal almandine with low $\mathrm{MnO}$ values, a population quite distinct from the diamond inclusions garnets. A small number of mantlederived peridotitic pyropes were reported by Bailey (1999) from rock concentrates, including some weakly depleted harzburgitic garnets. Possible eclogitic garnets with little or no $\mathrm{Na}$ are present in the concentrates.

\section{Pyroxenes}

Dachine diamond inclusion pyroxenes (Table 1, Fig. 4) include one eclogitic in style (DACBS 4A-2), but with an order of magnitude lower LREE compared to world data, lower LILE, $\mathrm{Cr}$ and $\mathrm{P}$, but higher in base metals e.g. $\mathrm{Mn}, \mathrm{Fe}$, $\mathrm{Co}, \mathrm{Ni}$ and also high in $\mathrm{Li}$ and Sc. The other clinopyroxene (DACBS 4B-7) has low Na but very high $\mathrm{Mn}$ and is of uncertain paragenesis locating below the world wide REE field for eclogitic clinopyroxene diamond inclusions (Fig. 4). Additionally it is extremely depleted in HREE.

Both diamond inclusion clinopyroxenes have low LREE compared to world-wide eclogitic diamond inclusions pyroxenes and strong Eu anomalies (Fig. 4).

In contrast, Dachine drill core concentrates (Bailey, 1999) include mantle-derived Cr-diopside and enstatite of typical mantle peridotite chemistry. 


\section{$1^{\text {th }}$ International Kimberlite Conference, Bangalore - 2012}

Single grain pyroxene thermobarometry (clinopyroxene: Nimis \& Taylor, 2000; orthopyroxene: Ramsay, 1992) suggests concentrate pyroxene originate over a range of $\sim 3 \mathrm{GPa}$ at $1000^{\circ} \mathrm{C}$ to $7 \mathrm{GPa}$ at $1300^{\circ} \mathrm{C}$ on a somewhat hot geotherm of $\sim 43 \mathrm{~mW} / \mathrm{m}^{-2}$. This implies the lithospheric mantle extended down to $\sim 200 \mathrm{~km}$ depth.

\section{Nitrogen content, aggregation characteristics and implications}

The low $\mathrm{N}$ ppm values from mass analysis are in agreement with our findings from FTIR analysis that some $50 \%$ of the stones would be classified as type II $(<20 \mathrm{ppm} \mathrm{N}$, as defined by Cartigny, 2005). Other stones range from nearly pure $\mathrm{Ib}$ to IaA-Ib forms in which the A aggregate was typically $<20 \%$, as also found for Dachine stones by Magee \& Taylor (1999) and Cartigny (2010).

Many stones showed peaks below $1000 \mathrm{~cm}^{-}$ ${ }^{1}$ which we ascribe to probable inclusions (?silicates). Some stones showed a peak at around $1150-1160 \mathrm{~cm}^{-1}$ which fits between positions for $\mathrm{Ib}$ or IaB peaks. It is uncertain whether this peak is due to inclusions. Alternatively it may represent a Ib-IaB mix due to possible passage of the infrared beam through a localised more aggregated $\mathrm{IaB}$ growth zone before passing on into Ib-rich diamond, given the often polycentric nature of Dachine diamonds.

The yellowish green and blue excitations under long wave ultraviolet light are indicative of the presence of $\mathrm{H} 3$ and $\mathrm{N} 3$ centres respectively (Moses et al., 1997). Pinkish responses have been assigned by Bruce et al. (2011) to green schist metamorphic effects.

The weak, type Ib dominant, nitrogen aggregation of Dachine stones implies a relatively short time of mantle residence, $<1 \mathrm{Ma}$ at mantle temperatures (Magee \& Taylor, 1999). These authors point out the diamonds could not have retained such weak aggregation if they had been at komatiite melt temperatures $\left(1700-1750{ }^{\circ} \mathrm{C}\right)$ for more than 24 hours.

\section{$\mathrm{C}$ and $\mathrm{N}$ isotopes}

Our $\mathrm{C}$ and $\mathrm{N}$ isotope results confirm earlier findings by Magee et al. (1999), McCandless et al. (1999) and Magee (2001) that the majority of Dachine diamonds have extremely negative $\mathrm{C}$ isotopic values. With the exception of 3 samples out of 29, the $\mathrm{N}$ isotopic compositions of the Dachine diamond population are distinctively positive, as found by Cartigny (2010), and show no discrimination for $\mathrm{N}$ concentrations. However, the only samples with negative (mantle-like) $\mathrm{N}$ isotopic compositions all have very light $\ddot{a}^{13} \mathrm{C}$ values $(<-25 \%)$, for which we have no explanation at present.

The lack of a peak around the mean mantle $\ddot{a}^{13} \mathrm{C}$ value of circa $-5 \%$ is not typical of mantle diamond of either $\mathrm{P}$ or E types (Fig. 5). This observation, with the combination of strongly negative $\mathrm{C}$ isotopes with many highly positive $\mathrm{N}$ isotopic values, is only matched globally by the isotopic compositions of sedimentary organics (Fig. 5). This implies the $\mathrm{C}$ and $\mathrm{N}$ source for these diamonds is likely to be subducted ocean floor sediments.

\section{CONCLUSIONS}

Rapid growth for Dachine diamonds is suggested by their small size, slightly aggregated, poorly shaped, unresorbed octahedral external forms with occasional cubes, and their internally polycentric, blocky cores, and very weak type Ib nitrogen aggregation state. Plastic deformation implies post-growth stress, and the stones have considerable surface etching and cracks, testament to their having been in disequilibrium-with their environment.

A subducted pelagic sediment origin is supported by both the $\mathrm{C}$ and $\mathrm{N}$ isotope values for the diamond samples. There are no alternative 


\section{$1^{\text {th }}$ International Kimberlite Conference, Bangalore - 2012}

reservoirs known to us with mean $\ddot{a}^{13} \mathrm{C}$ values $<$ $20 \%$ and $\ddot{a}^{15} \mathrm{~N}$ values at around $+6 \%$. This evaluation includes bulk $\mathrm{C} 1$ chondrite, organic and inorganic fractions therein, bulk enstatite chondrite and Martian meteorite data; therefore making any proposal for primordial heterogeneities difficult to accept. The silicate and sulphide inclusions are eclogitic and therefore support the initial conclusion. The domination of organic carbon like $\ddot{a}^{13} \mathrm{C}$ values $(<-15 \%$ ) over carbonate-like $\ddot{a}^{13} \mathrm{C}$ values $(0 \pm 2 \%)$ leads us to presume the sediments were carbonate-depleted due to a lack of carbonate precipitating microorganism $>2 \mathrm{Ga}$ in deep Palaeoproterozoic Oceans.

In contrast concentrates from the Dachine host rock contain crustal almandine pyrope with low Mn content, abundant high $\mathrm{Cr}$ magnesiochromite zoned with rims richer in $\mathrm{Fe}$ and $\mathrm{Zn}$ (a greenstone metamorphic signature) and a minor peridotitic mantle mineral assemblage including dominant lherzolitic Cr-pyrope, occasional harzburgitic low-Ca pyrope, chrome diopside, orthopyroxene and rare picroilmenite. Single pyroxene thermobarometry of concentrate pyroxenes gave a temperature range from $1000^{\circ} \mathrm{C}$ at $3 \mathrm{GPa}$ to $1300^{\circ} \mathrm{C}$ at $7 \mathrm{GPa}$. This implies the Dachine host rock intruded mantle lithosphere from $\sim 200 \mathrm{~km}$ depth upward and makes it likely that the diamonds would have formed at that depth or deeper.

A possible reaction for diamond formation, $2 \mathrm{FeS}+\mathrm{CO}_{2}=2 \mathrm{FeO}+\mathrm{S}_{2}+\mathrm{C}$ (diamond), requires 4.3-5 GPa and $1050-1350^{\circ} \mathrm{C}$ (Marx, 1972). These pressure-temperature requirements fall within the range established from thermobarometry of peridotitic pyroxene from concentrates from the Dachine host rock.

The eclogitic (basic) mineral inclusion paragenesis, sulphide inclusion abundance, Mnenrichment of silicate inclusions, and dominant very light $\mathrm{C}$ isotopes and heavy $\mathrm{N}$ isotopes strongly suggest origin from a protolith of metamorphosed subducted sea floor sedimentary ooze enriched in base metals by exhalative volcanic activity. Differing REE patterns for the two clinopyroxene inclusions demonstrate chemical heterogeneity in the diamond-forming medium.

\section{ACKNOWLEDGEMENTS}

Rio Tinto Desinvolvimentos Minerais Ltda. is thanked for provision of diamond samples. The EIMF Centre, Edinburgh, is acknowledged for trace element analyses of garnets and clinopyroxene inclusions. S.Mikhail thanks the Diamond Trading Company and the Engineering and Physical Sciences Research Council (EPSRC) for financial support.

\section{References}

Bailey, L.M., 1999. An unusual diamond-bearing talc schist from the Dachine Area of French Guiana. M.Sc. Thesis, Queen's University, Kingston, Ontario, Canada, 159 p.

Bulanova, G.P., Varshavsky, A.V., and Kotegov, V.A., 2005. A venture into the interior of natural diamond: genetic information and implications for the gem industry. Part 1: The main types of internal growth structures. Journal of Gemmology, 29;7/8, 377-386.

Bruce L.F., Maya G., Kopylova M.G., Longo M., $\dagger$ Ryder J, and Dobrzhinetskaya, LF, 2011. Luminescence of diamonds from metamorphic rocks. American Mineralogist, 96, 14-22.

Capdevila R., Arndt N., Letendre J., Sauvage J.-F., 1999. Diamonds in volcaniclastic komatiite from French Guiana. Nature 399, no. 6735, 456-458.

Cartigny P., 2005. Stable isotopes and the origin of diamond. Elements 1, 79-84

Cartigny P., 2010. Mantle-related carbonados? Geochemical insights from diamonds from the Dachine komatiite (French Guiana). Earth and Planetary Science Letters, 296, Issues 3-4, 329339.

Dube, B., Mercier-Langevin, P., Hannington, M., Lafrance, B., Gosselin, G., and Gosselin, P., 2007. 


\section{$10^{\text {th }}$ International Kimberlite Conference, Bangalore - 2012}

The LaRonde Penna world-class Au-rich volcanogenic massive sulfide deposit, Abitibi, Québec: mineralogy and geochemistry of alteration and implications for genesis and exploration. Economic Geology, 102, 633-666.

McCandless, T.E., Letendre, J., and Eastoe, C.J., 1999. Morphology and Carbon Isotope Composition of Microdiamonds from Dachine, French Guiana. In: J.J. Gurney, J.L. Gurney, M.D. Pascoe, \& S.H. Richardson (Eds.), Proc. 7th International Kimberlite Conference, Cape Town, 1998, P.H. Nixon Vol.2, 550-556.

Magee, C.W. 2001. Geologic, microstructural, and spectroscopic constraints on the origin and history of carbonado diamond. Ph.D. Thesis, Australian National University.

Magee, C.W., and Taylor, W.R., 1999. Diamond and chromite geochemical constraints on the nature of the Dachine complex, French Guiana. Research School of Earth Sciences, Australian National University, Annual Report 1999, 85.

Marx, P.C., 1972. Pyrrhotine and the origin of terrestrial diamonds, Mineralogical Magazine 38, 636-638.

Moses, M.T., Reinitz, I.M., Johnson, M.L., King, J.M., and James E. Shigley, J.E., 1997. A contribution to understanding the effect of blue fluorescence on the appearance of diamonds. Gems and Gemology, Gems \& Gemology, 33, No. 4, 244-259.

Nimis, P, and Taylor, W.R., 2000. Single clinopyroxene thermobarometry for garnet peridotites. Part 1.
Calibration and testing of a Cr-in-Cpx barometer and an enstatite-in-Cpx thermometer. Contrib. Mineral. Petrol., 139, 541-554.

Ramsay, R.R., 1992. Geochemistry of diamond indicator minerals. Ph. D. Thesis, Univ. of Western Australia, $1101 \mathrm{p}$.

Schwandt, C.S., Papike, J.J., Shearer, C.K, Brearley, A.J., 1992. Crystal chemical control of REE incorporation in garnets from the Broken Hill $\mathrm{Pb}$ $\mathrm{Zn}-\mathrm{Ag}$ orebodies, Australia. Canadian Mineralogist 31: 371-379.

Spry, P.G., and Wonder, J.D., 1989. Manganese-rich garnet rocks associated with the Broken Hill leadzinc-silver deposit, New South Wales, Australia. Canadian Mineralogist, 27, 275-282.

Stachel, T., Aulbach, S., Brey, G.P., Harris, J.W., Leost, I., Tappert, R., Viljoen K.S., 2004. The Trace Element Composition of Silicate Inclusions in Diamonds: A Review. Lithos 77: 1-19

Sun, S-s., and McDonough, W.F., 1989. Chemical and isotopic systematics of oceanic basalts: implications for mantle composition and processes. In: Saunders, A.D. and Norry, M.J. (eds), Magmatism in the ocean basins, Geological Society Special Publication, 42, 313-345.

Wyman D.A., O’Neill, C.O., and Ayer, J.A., 2008. Evidence for modern-style subduction to $3.1 \mathrm{Ga}$ : A plateau-adakite-gold (diamond) association. In: K.C. Condie and V. Pease (Eds.), When Did Plate Tectonics Begin on Planet Earth? The Geological Society of America Special Paper 440, 129-147. 